\title{
"Once upon a Time in ... ethnocratic Australia: migration, refugees, diversity and contested discourses of inclusion and exclusion"
}

\author{
Andrew Jakubowicz \\ University of Technology Sydney
}

\begin{abstract}
To what extent can Australia be analysed as an 'ethnocracy', a term usually reserved for ostensibly democratic societies in which an ethnic group or groups control the life opportunities of a more widely ethnically diverse population? Australia adopted its first refugee policy in 1977 having been forced to address the humanitarian claims of Asian and Middle Eastern refugees. Only a few years after abandoning the White Australia policy of three generations, the public discourse about refugees was framed by the ethnic origins of these groups (primarily Vietnamese and Lebanese). Over the decades a utopian light has come to be cast on the Indo Chinese as a success story in settlement, while the Middle Eastern peoples have been shaded as a settlement failure. Yet the counter narratives developed in the SBS television documentary series “Once Upon a Time...” demonstrate how ethnocratic framing can be challenged and more nuanced and analytical discourses introduced into the public sphere.
\end{abstract}

\section{Introduction}

Attitudes to asylum seekers and refugees among Australians are said to depend on two factors - first, that the government has control of Australia's borders and therefore the only refugees who enter have been determined to meet Australia's sense of what a 'good settler' needs to be; and second, that 'good settlers' integrate, contribute and do not cause disharmony (Eureka Research 1998). These narratives when applied to 'deserving' and 'undeserving' contemporary refugees reflect deeply entrenched views formed initially at the end of White Australia in the mid-1970s, when the country for the first time took non-European immigrants in significant numbers. At that time, and unexpectedly for policy makers, the Australian Government had to revise its policies on refugees in the face of world-changing struggles overseas, in Vietnam and in Lebanon, which transformed the sources of immigrants and patterns of settlement from then on (Jupp 2007).

Andrew Jakubowicz, Faculty of Arts and Social Sciences, University of Technology Sydney.

Corresponding author: Andrew.Jakubowicz@uts.edu.au

ISSN: 1837-5391; https://epress.lib.uts.edu.au/journals/index.php/mcs

CCS Journal is published under the auspices of UTSePress, Sydney, Australia

(C) 2016 Andrew Jakubowicz. This is an Open Access article distributed under the terms of the Creative Commons Attribution 4.0 Unported (CC BY 4.0) License (https://creativecommons.org/licenses/by/4.0/), allowing third parties to copy and redistribute the material in any medium or format and to remix, transform, and build upon the material for any purpose, even commercially, provided the original work is properly cited and states its license. 
These two communities - Vietnamese (Lewins 1984) and Lebanese (Humphrey 2007) - have featured in the debates about immigration for forty years, and have oscillated in the public mind between good and bad. While such a simplistic dichotomy may appear to have limited value in providing a nuanced scholarly analysis of contemporary arguments over immigration, an analysis of their situations and the 'push-back' against simplistic and destructive stereotypes exposes the importance of resistance narratives in the political culture of national identity which challenge the choices made by political leaders in 'narrating the nation' to the public (Jupp, Nieuwenhuysen \& Dawson 2007).

The central argument of this article takes the demonstrated impact of these 1970s refugees on public discourses about national stereotypes in the first decade or so of their settlement. The article proposes that this ethnic dichotomy, reversed in focus, now frames debates about contemporary refugee arrivals. It is this deeply embedded cultural framing of people based on ethnic origin that marks Australia as an ethnocratic political space (Pullan \& Baillie 2013).

The anti-Asian phobia captured by the intervention of the prominent historian Prof Geoffrey Blainey in 1984 funnelled the rise of the push-back against multiculturalism (Lewins 1987). This culminated in the first election of the far-right Pauline Hanson, and what later became her 'One Nation’ party, to Parliament in 1996 (Jakubowicz 1997). The social movements that have currently formed around the contemporary politics of refugees carry thematic impressions from the 1990s, given sharpened focus following the July 2016 re-election of Hanson and three other One Nation Party senators. Once more, the fierce arguments over border control illuminate the ways in which ethnocratic power in Australia is expressed, imposed and resisted.

Across this period there were however important indications of ethnic community resilience, reflecting wider settlement narratives. These were explored in depth through two television documentary series focused on the experience of the Vietnamese and the Lebanese migrants. Under the title 'Once upon a time in...', they explored otherwise obscured local suburb-level narratives, and were broadcast in 2012 and 2014, at the height of political debate over turning-back asylum seeker boats (Ngo 2011). This article reflects on these experiences and on the documentaries themselves, as a counterpoint to the wider public debate and its 
persistent ethnocratic dimensions. The conclusions point to Australia’s 'ethnocratic securitisation', and to the alternative narratives that mobilised against it.

\section{1. 'Ethnocracy' in an Australian city: Sydney and its ethnic spaces}

In November 2016 the Australian Liberal National Coalition government's Immigration Minister, Peter Dutton, launched a sustained attack on the 1976 decision of a former Liberal Prime Minister, Malcolm Fraser, to allow Arab Muslims fleeing from the civil war in Lebanon, to be given refuge in Australia (Hewson 2016). It was the children and grandchildren of these under-qualified refugees, he claimed, who had grown up to become home-grown terrorists and had travelled to the battle grounds of Syria and Iraq to join the thousands of 'foreign fighters' supporting the expansion and defence of the Islamic State (Anderson, S. 2016; Davidson 2016).

It is very rare for major figures from either side of the political divide to target particular ethnic groups en masse as a 'failure' or a 'danger' to Australia. It had been the typical rhetoric and ideology of early Australian nationalism in the late $19^{\text {th }}$ century, especially against the Chinese (Rivett 1962). This form of ethnic framing was supposed to have been abandoned with the adoption of a multicultural perspective in the late 1970s. Even so, the last significant criticism of this type was proffered by the Immigration minister in the Howard coalition government, Kevin Andrews (Harrison 2007). In 2007 he voiced his belief that African refugees were failing to 'integrate’ into Australian society, and their migration should therefore be halted (Jakubowicz 2010). Dutton took aim at this same group of African settlers in a second salvo when announcing an Inquiry (also in November 2016) by the Joint Parliamentary Migration Committee into youth crime in Melbourne, supposedly associated with African communities (Parliament of Australia 2016).

In the previous week the conservative News Ltd. media had run a series of stories pointing to the 'failure' of many post-refugee communities to integrate, arguing high rates of dependence on social security payments of various sorts meant they had failed in the job market (or never even tried) (drawing on Morton 2016). The named groups included people from the Middle East (especially Lebanon) and from Africa. Sky News commentator Andrew Bolt has summarised this narrative of threat on Facebook, where he demanded that "politicians 
acknowledge that culture counts - it must be a factor when deciding who we let into Australia” (Bolt 2016).

A description of these political moments serves to introduce and expand on the concept of 'ethnocracy', the theme of this special issue. 'Ethnocracies' as James Anderson has defined them, are societies (or even regions in societies) that are characterised by hierarchies of ethnic power.

Ethnocracy basically means 'government or rule by an ethnic group' or ethnos, and more precisely rule by a particular ethnos in a multi-ethnic situation where there is at least one other significant ethnic group. Ethnicity and group self-awareness can be specified in terms of religion, imputed 'racial' features, language, and/or a shared history and culture more broadly defined, components which vary and sometimes in problematic ways. (Anderson, J. 2016, p. 1).

These hierarchies find their realisation in the day-to-day constraints and barriers experienced by ethnic groups, despite claims in the political realm by the ruling elites that no such barriers exist, or if they do, they are produced by the subordinated ethnic cultures. This is a focus of the analysis that Oren Yiftachel used in developing the concept in relation to Israel and its divided cities (Yiftachel 2006)

Often these barriers (expressed in unemployment, drug or alcohol abuse, crime, violence and depressed local economies) become a focal point for discursive power, with narratives explaining identifiable ethnic disadvantage directed to highlight the supposed cultural failings of the groups concerned. The key dynamic of discursive power in ethnocracies lies in the constant reiteration that those who are marginalised have the opportunities to overcome their social position, but choose not to so for nefarious and manipulative reasons or are culturally incapable of doing so.

While Australia has a long history as an 'outed' ethnocracy in the period between 1901 and 1973 under the White Australia policy (Tavan 2004), by the mid-1970s governments of both political persuasions (Labor first and then the Liberal-National Party Coalition) had abandoned racial definitions of the national project, and withdrawn racial and religious barriers to immigration. In that context a new policy framework, 'multiculturalism', was developed and advanced, shaping Australia for a post-racialised place in a globalising world 
of highly mobile labour. 'Multiculturalism' has as its basic trope the condemnation of ethnocratic power, and the denial of its contemporary persistence in any serious way (Borowski 2000).

During the birth pains of that policy shift from White Australia in 1976, Australia was confronted with two major refugee crises - the end of the Indo-China wars with the exodus of tens of thousands of Vietnamese, Cambodians and Laotians, from countries then governed by military-backed Communist regimes; and the exodus prompted by widespread bloodshed caused by the primarily inter-faith and sectarian conflict between Christians and Muslim citizens of Lebanon. The popular narratives associated with the arrival, settlement and growth of these two communities appear to have set the discursive boundaries for current interpretation of 'successful' settlement and 'failure'. In contemporary Australia the mainstream media tend to paint the Indo-Chinese as the dream story of escape, renewal and success, while the Muslim (primarily Sunni) Lebanese are portrayed as criminals, terrorists and jihadists (Noble, Poynting \& Collins 2000). This sense-making is so pervasive that it affects the response to and management of asylum seekers who take the unauthorised maritime route towards Australia (Tsiolkas 2013).

\section{Settlement anxieties: ethnocracy revived?}

The metropolis of Greater Sydney has a population of about 4 million people in 2016. Due to its topography and transport routes, and the location of migrant hostels in working class areas (where arriving refugees are often first housed), the geography of Sydney is somewhat ethnically segmented. While no suburbs are overwhelmingly identified with one ethnic group, many ethnic groups tend to be concentrated in locations associated with accessibility to key services, especially religious buildings, food stores, cheap housing and proximity to coreligionists or language speakers. In the case of Sydney, first generation Indo-Chinese settlement focussed on the Fairfield municipality and especially the suburb of Cabramatta, while Muslim Lebanese settled in the region of Canterbury Bankstown in suburbs such as Lakemba and Punchbowl.

The history of political and related media discourses about ethnic groups demonstrates a long slow 'build' of negative perceptions (Jakubowicz 1994). As Teun van Dijk has demonstrated in a strong body of work exploring the media construction of racial sterotypes (van Dijk 
1991), media discourses play a central role in shaping public attitudes towards immigrants, and influence the shaping and delivery of policy and programs.

Until 1977 Australia did not have a refugee policy per se, but rather took in refugees as immigrants when sponsored by approved agencies. The decision to have a refugee policy, first made in 1977, thus sets the opening moves in the process of incorporating ethnocratic societal maps into policy over asylum seekers (Neumann 2015). In fact the recognition of its ethnocratic dimension (namely the use of state power to limit and define the possibilities of survival differently for different ethnic or religious groups) provides a necessary dimension for analyzing and ultimately modifying the policy positions that have arisen. These positions, while speaking in the name of humanity, actually serve to restrain those ethnic groups which are essentially escaping failed states or their own tenuous minority status under authoritarian regimes, from securing safety.

In his 1977 speech to Parliament the Federal Immigration Minister in a conservative government, Malcolm Mackellar, outlined Australia’s commitment to the UN Refugee principles, while describing the lack of structure for managing applications for people seeking refuge who did not have pre-existing family in Australia (Mackellar 1977). He argued there needed to be a framework for those future crises that Australia would be sure to face as part of the international community, such as those described by a Senate Standing Committee the previous year (Senate 1976).

At that time the main game was definitely in Indo-China and the uncontrolled exodus of those fleeing the victory of national liberation forces. The Australian Government was being lobbied by an NGO coalition (the Indo Chinese Refugee Association ICRA) to accept some 4000 people from the refugee camps in Thailand, Malaysia and Hong Kong following the end (or loss by the West) of the Indo-China Wars. Under the direction of the Prime Minister, Malcolm Fraser, it negotiated a regional agreement that saw Australia accept some 10,000 Indo-Chinese refugees each year for the next decade, far beyond the lobby's aspirations (Colebatch 2010).

Almost simultaneously, in the Middle East, Minister Mackellar was driven to act following threats to Australian migration posts in Lebanon charged with responding to the situation generated by the civil war. In particular, with the closure of the Australian post in Beirut, and 
withdrawal of personnel to Damascus and Cyprus, a more regularised system had to be put in place. In a very significant move, in 1977 the family-sponsored migration advocated by the Christian Lebanese community for its own people was extended to non-discriminatory humanitarian entry for Muslim Lebanese refugees (Higgins 2016).

These mid-1970s refugee 'moments' have entered the public discourses about Australian political culture in relation to global refuge-seeking: the Fraser Indo-Chinese decisions have been framed as a utopian bi-partisan regionally-supported intervention with very positive longer term outcomes, enabling the eventual settlement of many hundreds of thousands of people from Vietnam, Cambodia and Laos (Vanstone 2004). As noted, after a first generation of difficulty and criminality (especially around the importation and sale of heroin from South East Asia and the embedding of crime triads), the Indo-Chinese are now seen for the most part as model minorities making significant contributions to Australia's development, a utopian project (Jupp 2002).

The dystopic model is attributed to the Lebanese Muslim intake of the decade after 1976. While the majority of refugees from Lebanon at that time in fact comprised Christians (mainly Maronite Catholics and Eastern Orthodox, a significant minority were Muslim. The Muslims were mainly Sunni, though there were also some Shi'a and other minority sects. The Sunni came to be branded as dangerous failures (Sheehan 2006). Although in fact the majority of the community was mainly a settlement success, it has also thrown-up a series of socially-challenging segments. The earliest appearance was in the illicit drug scene, where Lebanese gangs fought for turf with Vietnamese triads (Tabar, Noble \& Poynting 2003). By the 1990s this had expanded into gang crimes of sexual violence, extortion, political support for anti-Western nation states (Iraq, Palestine, Libya), and soon thereafter into religiouslyframed violence. These perspectives associated 'people of Middle Eastern appearance', as the police identified them, with deeply destabilising anxieties about the social order, exacerbated by media moral panics (Noble, Poynting \& Collins 2000).

There is evidence then that the framing of the refugee narrative within the fears and practices of an ethnocratic state such as Australia, or its local variant in New South Wales and its capital city, Sydney, continues to provide the criteria for judging the quality of refugee integration in ways that see the culture of the arrivals as all-determining, and their relationship with the state or civil society as essentially irrelevant. The refugee policies that 
opened Australia to the presence of Indo-Chinese Catholics and Buddhists, and Muslim Arabs, were forged as the ground rules for interpreting these new waves were starting to emerge in public discourse and government action or inaction.

The narrative around Vietnamese was more destructive and 'excited' early on in their settlement. By 1984 anti-Asian rhetoric was rising, captured by Australian historian Geoffrey Blainey's controversial claims that Asians were threatening Australian social cohesion due to their failure to integrate, heightened by competition for working class jobs in a declining economy (Jakubowicz n.d.). A decade later (1996) the regular reporting of Cabramatta as a centre for drugs and violent crime helped the independent nationalist politician Pauline Hanson secure her election to Federal Parliament on a platform that included her goal to stop Australia being 'swamped by Asians' (to be refreshed 20 years later when the swamping was by Muslims after her election to the Senate in 2016). Anti-Asian sentiment reached its height in the aftermath of the Coalition win at the 1996 election, with a survey carried out by the government in 1998 showing widespread antipathy to Asians, but almost no expression of concerns about Muslims or Lebanese (Eureka Research 1998).

By 2001 the situation had reversed. There were many reasons for this shift in public attitudes - though primarily it can be sourced to a re-direction of public excitement in the media to Lebanese Muslims. This Islamisation of fear was heightened by new waves of 'boat people' from Afghanistan and the Middle East (Marr \& Wilkinson 2003), the 2001 September suicide and murder attacks on New York and Washington, and soon thereafter, the murder of Australian tourists by Indonesian Muslim jihadists in Bali (Jakubowicz 2007). While the refocus on Muslims paralleled the rise of trans-national Islamist ideologies, in Sydney it was intensified by a constellation of factors - some specifically Lebanese, some more generally Sunni, some over-archingly Muslim (collecting Shi’a and others). In particular there were two arenas of criminal behaviour that became 'Middle Eastern' in media interpretation - a murder of an outsider in Punchbowl's Telopea Street by members of a drug gang made-up mainly of young Australian Lebanese Muslims, and the kidnapping and rape of young women by men also understood to be from Muslim Middle Eastern backgrounds (Jakubowicz 2015). 


\section{Shifting the Narrative: The 'Once upon a Time' series...}

The media stigmatisation and stereotyping of Vietnamese and Lebanese communities as criminal and dangerous, with their leaders as ineffectual, or uncaring about the consequences, was a matter of deep concern to the wider Lebanese and Vietnamese communities. The Special Broadcasting Service (SBS), a Federal government media organisation, had been concerned for some time about how they could enter the contested narrative, which was contributing to the marginalisation of communities that had first sought refuge in Australia some thirty-five years before. In 2011 SBS commissioned a series from the documentary producer Northern Pictures, to be named “Once Upon a Time in...” (OUATI...), covering the experience of the Vietnamese in Cabramatta and Lebanese (of all sects) in Punchbowl. Both documentaries were made at a time when there was increasing apprehension about 'unauthorised maritime arrivals’ (refugees arriving by boat), and as the spread of Islamist terrorism was becoming a major concern of domestic security organisations. It is important to comprehend that while the documentaries were offering a historical narrative they were also providing a contemporary commentary on public debates.

The 'dark' ethnocracy that prevailed in the wider media and was apparent in the discourse of conservative politicians had played a role in marginalising communities towards whom the rhetoric and representation were directed. It also contributed to the more anti-social counternarratives developed among the criminal gangs and then the sectarian groups that emerged through the socialisation of the second generation in Australian society.

The SBS Cabramatta series (OUATIC) began with some key structural ideas that provided a frame for a dramatic telling and development of a redemptive counter-narrative. In the case of the Vietnamese, the boundaries were set for an exploration of a community development trajectory among escapees from a civil war. They had no pre-existing community structures in Australia. Prior to 1976 during White Australia, there had been hardly any Vietnamese in Australia - usually only students under the Colombo Scheme. Some of the post-war arrivals were unaccompanied teenagers, while many of the adults (outside those who were officials of the defeated South Vietnamese regime) were poorly educated and with no English skills. Some had arrived by boat after dangerous voyages through the South China Seas, others had been selected from camps in Thailand and Malaysia. After 1978, regional agreements with the government of Vietnam opened up opportunities for family reunions under orderly departure. 
The Vietnamese SBS program theme had two elements - the first Asian community immigration on a significant scale since the $19^{\text {th }}$ century occurred before the institutions of multiculturalism had been created and in the umbra of the long slow death of White Australia. In the chaotic and unplanned settlement zones 'all was chaos, and the first thing to get organised was crime' (Jakubowicz 2015). So the narrative had to recognise the criminal dimension, how it emerged, what its effect was on the cohesion of the community, and how it was able to grow in a period of widespread police corruption. It demonstrated what an ethnocracy actually felt like for those entrapped within it, as parents struggled to understand their children, and rescue them from the gang culture and heroin scene that spread quickly through the community. More particularly it demonstrated the abandonment of the community by the authorities and therefore the vulnerability of marginalised people to the depredations imposed on them by their own criminal edge.

The key interviewees included a gang member who recalled the attractions of the sub-cultural life of crime, money, sexual freedom and violence; his redemption was in evangelical Christianity. Another was a small-time drug dealer and user whose parents decided to make him go cold-turkey, and save him from the life on the street - both him and his parents participated in the program; they now have a successful small business together. Another was a Vietnamese man who had grown up in a Westernised family outside the area, and had returned to discover his roots, only to become deeply involved in the politics of redemption. He became a member of the local Council, an active advocate for change and the rights of Vietnamese Australian citizens to peaceful and enriching lives. Others interviewed included Anglo-Australian business people, police, and academics.

The last episode tracked the period of redemption, highlighted by the counter-narrative advanced by Asian members of the State parliament in conjunction with cross-ethnic community leaders from Cabramatta. An Upper House Inquiry led by a Chinese Australian MP from the area, into the policing of Cabramatta revealed serious corruption. It foregrounded the belief of the police that corralling the heroin scene in Cabramatta made it easier to monitor, while they had little empathy for the primary victims, local Vietnamese Australians, or those caught up in inter-gang violence. 
In moving to pre-empt the report of the Inquiry, the State Labor Government finally acted in what they had always taken for granted as a safe Labor constituency, undertaking mass arrests of dealers, introducing area-based and coordinated delivery of State services, and a strongly improved drug rehabilitation program. The final scenes of episode 3 of OUATIC showed the outcomes for a number of families - a son rescued from heroin through tough love, the streets cleared of dealers and addicts, and a prosperity returned to the town centre. In 2016 Cabramatta is on the urban culinary tour map of Sydney, and a centre for the expression of a syncretic and vibrant Australia-Vietnamese culture. Generation 3 are now fully integrated into the wider life of Sydney, with a high number of graduates in the professions. The Vietnamese story is now being hailed as a success (Thomas 2015), with the struggle and the political barriers that had to be overcome unremarked in the narratives that portray the contemporary ethnic scene in Sydney.

The response to the broadcast of the Cabramatta series was very positive. While some viewers thought the disappearance of dealers from the town was not as total as might have been suggested, and indeed the criminal edge of the Vietnamese community continues, the majority commented that for the first time it allowed a narrative from within the community to test and challenge the stereotypes imposed over decades. The series unwrapped how ethnocracy can come to overwhelm democracy, and also how local struggles can help to recompose the wider narrative, and thereby move the pendulum more generally towards the democratic centre. Cabramatta remains a safe Labor Party State seat, though concerted attempts by Liberal and now independent politician Dai Le, who arrived as a child after a dangerous sea journey, have shown that the old order has changed.

The second series, based on Punchbowl, complicates the idea of ethnocracy. While the Vietnamese arrived in 1975/6 to a space with no previous Vietnamese settlement, after the end of formal White Australia but before formal multiculturalism, there had been Arab Settlers from the Middle East and the Syrian/Lebanese region of the Ottoman Empire since the mid- $19^{\text {th }}$ century. Many had started as travelling pedlars moving through rural areas carrying city goods, and then created stores in rural towns. Later their families had become business people and professionals (such as Dame Professor Marie Bashir, former Governor of New South Wales, whose husband Nicholas Shehadie had been a rugby union international, Lord Mayor of Sydney, and chair of SBS in the 1980s). This community was primarily Christian - usually Maronite Catholic, Melkite (Greek Catholic), or eastern Orthodox. It was 
really only in the 1960s that the first Muslims arrived, and then large numbers came during the civil war after 1976. A long established community that had been apparently well integrated was confronted with the trauma of war and displacement, rapidly changing its class and sectarian composition.

Once Upon a Time in Punchbowl (OUATIP) released in 2014, tracked the longer trajectory of the Lebanese population in one suburb through the arrival in 1976 and 1977 of thousands of primarily Muslim refugees from the civil war. The original pressure for Australia to open its migration channels to Lebanese refugees came from the established Christian Lebanese communities, who feared for the well-being of their co-religionists being attacked by various Muslim militias, of both Sunni and Shi’a identities.

As the Muslim communities arrived they found an environment where there were few Lebanese Muslims, the overwhelming Lebanese Arabic community being the Christian often Francophile groups that had been arriving for decades, despite a pre-War break at the height of White Australia (Monsour 2006). As with the Vietnamese, whose time of arrival fairly much paralleled their own, among the Lebanese there were many families and individuals deeply scarred by the conflict, and lacking key cultural capital in relation to language and skills suitable for an advanced capitalist economy. On the edges here too there were people with criminal pasts including in the drug trade in the Bekar valley of Lebanon, who sought out opportunities to continue their illicit lives.

The series mapped out the key set pieces, points at which the tensions within and between the Lebanese communities began to be displayed. Essentially the first decade or so of settlement was characterized by orientation, job-seeking and family formation. The Christian communities were uncomfortable with what many of them saw as 'the enemy' arriving unexpectedly, despite their leaders' warnings to the Fraser Liberal government about the dangers of importing these conflicts. The Immigration Department, new to the idea of nonEuropean refugee arrivals not mediated by Australian agencies, noted that many of the refugees, though desperate to leave, were not as skilled as previous refugee arrivals from Europe. These had included the Holocaust survivors and Displaced persons after the Second World War, or from Hungary in the 1950s or Czechoslovakia in the 1960s (Neumann 2015). 
The series was not designed to accept uncritically these negative narratives about the Lebanese, though at the same time it did not try to ignore many of the crisis points that marked the rising negative impact of the Lebanese settlement story on Australian public opinion and the mainstream media. The narrative arc began with the moment of arrival and followed the communities (both Christian and Muslim) as they tried to come to terms with each other in a new location, building as they went networks of influence and power to bolster their survival. It took as its theme the coda "In a society of Honour and Shame, what happens when Honour turns toxic?”.

The key events each demonstrate (on reflection) dimensions of ethnocratic power and its impact on an often-reeling community. In 1993, an Arabic community picnic day was terrorized as a small altercation in a Tempe (an inner city suburb of Sydney) park descended into a near riot, sparked by the arrival and intervention of mounted police and dogs. This presentation of the Arabic community (not identified by religion) as potentially violent and unruly, did not reflect the realities of life in their neighbourhoods. However it did follow soon after the first questioning of the national loyalty of Arabs, a focal point of media attention during the first Gulf War (1990-1991) when camera crews toured the streets of Arab Sydney interrogating passers-by on their allegiances.

However the 'descent' in the public mind began in earnest in the late 1990s, in part because of conflicts between Lebanese gangs and those from Vietnamese backgrounds in Cabramatta, and more widely in Bankstown, a key suburb in western Sydney. In 1998 a drug gang in Telopea Street, Punchbowl was raided by police after months of complaints from the public and inter-group violence. The murder of Edward Lee, a 14 year old Korean Australian student, by gang members, and the arrest of others for dealing turned a spotlight on gang life in the West, resulting in a police focus on criminals of "Middle Eastern Appearance", and the creation of the Middle Eastern Crime Squad (MECS). From 2000 the public narrative became overwhelmed by negative imagery, that 'bleeds' across to touch everyone of Lebanese background and Muslim faith. A series of gang rapes sensationalized the stereotypes even more vividly, compounded by the Imam of the Lakemba Mosque Sheikh Hillaly using overtly demeaning language to discuss the behaviour of women. The series of bombings that took place in New York and Washington, Bali and London, claiming many lives, refocused public attention on something that was supposedly uniquely Islamic in form and practice. 
The 2005 Cronulla riot, a confrontation between 5000 non-Muslims and a few Muslims arising from months of hostility over the Lebanese presence at this city ocean beach suburb (Jakubowicz 2009), intensified the relevance of ethno-political frames of reference. The conflicts said to exist between Muslim and non-Muslim communities expressed the fragmenting of stalemates that had been part of the ethnocratic structuring of multicultural Sydney. Usefully, the conceptual frame offered by ethnocratic theory can be appropriated, both to critique alleged Muslim behaviours, and to critique those who are seen as the oppressors of Muslim rights in Australia. From both perspectives, ethnocracy is exposed as a set of power relationships, enacted in particular interchanges. From this perspective the original riot in Cronulla in 2005 can be seen as a racialised claim by the White defenders of Cronulla beach to exclude those (the 'Lebs') whom they detest and distrust. The return to Maroubra (another seaside suburb in the south-east of Sydney) and the assaults on local residents by the remnants of the Telopea Street gang and another gang, the Punchbowl Park boys, marks an attempt, albeit violent, to return to the enemy's space and re-appropriate it by assaulting this enemy's feelings of White safety.

For a multicultural society such readings are deeply disturbing. Multicultural policy claims that inter-group relations occur on a democratic and egalitarian playing field. The behaviour in Cronulla in 2005 suggested the opposite (Jakubowicz 2007). In the final episode of the documentary (OUATIP), the people are redeemed, though not freed, through the contribution of the new generation exemplified in the family of Jihad Dib. The family was the epitome of success, with Jihad a highly successful and transformative high school teacher, later to become the first Muslim member of the Legislative Assembly in the NSW Parliament.

While both series looked-for and highlighted hopes for the future in the rebuilding of communities, in the public debate of the mid-2010s redemption has only been allowed to the Vietnamese. The uproar occasioned by the Minister for Immigration and Border Protection, Peter Dutton's comments about the Lebanese arrivals producing terrorist offspring, reveals no sense among those who share his perspective (as in the journalist Andrew Bolt) that they have been redeemed. The documentaries attest to the main argument of this paper, that narratives about the place of minorities in Australia society reveal how much the policy discourse of multiculturalism actually reflects serious struggles for and against ethnocratic power. These struggles, resurfacing in a particularly vituperative form after the election of Donald Trump as President of the USA in November 2016, have been emboldened thereby 
on the side of those advancing the White ethnocracy. Immigration especially of refugees has become an increasingly central defining block of contemporary politics, with an antiImmigration party One Nation likely to be influential in the (Australian) Federal Senate for some time.

\section{4. 'Unauthorised' arrival: a new ethnocratic narrative}

The election of the conservative Howard Liberal-National Party Coalition government in 1996 moved the political discourse on refugee settlement back towards the more Anglocentric and nationalistic view of Australia, and away from the more multicultural global perspective; indeed this popular fear of any 'opening to Asia' drove much of the support for the conservatives (Betts 2008; Gordon \& Topsfield 2006). That moment was marked by the first election of right-wing nationalist Pauline Hanson as a break-away from Howard's party. Her political performance since that time has provided a simple but portentous guide to the strength of white nationalist ideology both electorally and discursively (Jakubowicz 1997).

The pivotal moment occurred in 2001, when under orders from Prime Minister John Howard, Australian armed forces turned away a container ship, the 'Tampa' (Tsiolkas 2013). The ship, through humanitarian motives, had rescued a contingent of asylum seekers from a leaking boat, and sought to deliver them to the safety of the nearest Australian port. Instead they were sent to Nauru Island, an independent liege state of Australia’s in the Pacific (Marr \& Wilkinson 2003).

'Tampa' has been indissolubly linked in the public mind with the attacks of 9/11 in the USA, and the supposed subterfuge by other asylum seekers in Western Australian waters at around that time in what became known as 'the children overboard' events of 2001. Drawing these events together conservative political forces were able to apply a narrative of manipulative dissimulation to asylum seekers, and naïve entrapment to their supporters (Andrews 2007).

The Government elaborated its response to the asylum seekers question through a range of stratagems. Most importantly it created a new 'tragic couplet', attaching the adjective 'illegal' to the noun 'refugee'. In the UN Convention seeking asylum or seeking to be a refugee cannot as such be defined as a criminal act (Clack 2000). Prior to 2001, asylum seekers were deemed to be unlawful entrants to Australia, whose successful claim for asylum would make 
them 'lawful'. By changing the words used, it became presented as illegal to even enter Australia without pre-arranged authorisation, so turning back boats and so on could be spoken of as lawful, as it purported to prevent an illegal act taking place (Editorial 2001). Legislation was passed to protect any Australian official participating in the expulsion of asylum seekers from any legal consequence. In 2001 the Coalition government also removed the whole coastal area of Australia from the migration zone, meaning that even if an entrant landed on the coast they were not technically 'in Australia' and therefore entitled to claim asylum and be heard (Jupp 2007). In 2013 the whole country was excised from the migration zone by the Labor government (Brown 2016).

The control narrative portrayed the arrival by boats as explicitly and equally criminal both for the seeker and the smuggler, and dangerous to the social order of Australia; the smugglers were portrayed as devious and caring only for profit, rendering them hard to stop. Technically though if an asylum seeker made it into Australia they could then activate the UN Convention provisions (as many do who arrive on other temporary visas by plane, and then seek asylum); hence, the increasingly extensive excisions of the land mass from its own migration zone. Secondly the asylum seekers were said to be a privileged group who had the resources to make the trip to Indonesia and then pay the smugglers; it was their wealth rather than their need that drove them, and they were really economic immigrants falsely declaring a refugee status. Even where they were 'real refugees', their wealth was said to allow them to leap-frog the thousands without resources but with equal or greater need languishing in camps overseas, or trapped in places of danger. By doing this they were seen to be thwarting the goal of UNHCR to regularise and prioritise the flow of refugees to accepting host countries such as Australia (Sampson 2015).

So the policy became to turn back boats that were intercepted in order to ensure the asylum seekers could not land in Australia, intervene where possible in Indonesia to ensure boats did not leave, and promise that no one taking the 'boat' option would ever settle in Australia, and would languish in holding camps off shore for so long as it took for them to both prove their refugee claims, and find some country willing to take them - potentially for ever (Brown \& Missbach 2016).

From 2001 to 2009, few boats attempted the crossing while those asylum seekers held on Manus Island and Nauru were slowly processed, and fed into Australia, NZ and some of the 
Nordic countries. Then in 2009 the Labor government changed the policy, allowing on-shore processing of refugee applications. This encouraged some 50,000 people to cross by sea to Australia in four years, well over a thousand dying at sea, and causing an overwhelming of the country's compassion and protective capacity. No 'balanced' approach could gain support from either the Opposition Liberal-National Party Coalition (supporting strong defence) or the Greens (supporting humanitarian acceptance), and the government was frozen, until it readopted the turn back and off-shore processing line from the Opposition. The memory of this debacle was one of the key elements in the election of the conservative coalition in 2013, and its re-election in July 2016. While the detail has changed, effectively the key components remain - turn back the boats, no entry ever to Australia, and indefinite punitive detention offshore unless re-settlement somewhere that is not Australia can be found.

It should also be recognised that Australia takes about 13,000 UNHCR identified refugees each year, who have been processed outside the country. During the Syrian refugee crisis, the Government agreed to take an additional 12,000 refugees from the conflict, specifying those from minority ethnic groups unlikely to be able to return (that is, not the Sunni Muslims whose significant numbers will ultimately be part of any power-sharing resolution in Syria). In September 2016 the Government announced an increase in the refugee intake, drawn mainly from camps in Central America (overwhelmingly Christian), who would be traded for processed refugees held offshore on Manus Island and Nauru. In November 2016 the government announced it had secured the agreement of the US Obama presidency to resettle some of the Nauru/ Manus refugees: at the time of writing there was no clarity as to whether the administration of President-elect Trump would honour the agreement. (McGuirk 2016).

The debate on refugees remains one sharply coloured by the specific conditions of Australian political history. It is unlikely that the policy on asylum seekers arriving by sea would have the same parameters, if the refugees were of the same of similar cultural and ethnic origins as the majority of Australian society. Both Andrew Bolt and Pauline Hanson, now joined as exemplary advocates of an ethnocratic hierarchy in Australia, have made their views on refugees clear - it is the cultural background of the refugees that is the problem, not merely their method of seeking refuge. 


\section{Deserving and undeserving: asylum seekers and the quality of mercy}

If the argument that ethnocratic hierarchy frames the assessment of how the acceptance of refugees retains its place in Australian global human rights practice, then we would expect two elements to be evident as is the case with the Bolt/Hanson comments identified above. The first relates to process, that is, that the refugees' avenues to arrival have failed to meet security and selection criteria relating to potential for successful settlement. The second focuses on the lack of cultural capacity of the asylum seekers to adapt to and survive within Australian society.

The Vietnamese/Lebanese ideal-types that have come to permeate the popular imaginary as polar opposites continue to be potent frames for discursive engagement. In the struggle between those social movements that assert an ethnocratic world view, and those which resist it, deserving and undeserving representations of asylum seekers are heavily linked to the assumed narratives of success and failure.

The supporters of the government position, and indeed those who want the government to become even more intent on the creation of barriers to refugee arrivals, focus on people from Muslim countries and Africa. Here they recount the consequences of Arab Muslim immigration in terms of crime, terrorism and social dislocation among their descendants. They make scarce mention of any other refugees, in particular avoiding issues of criminality and violence elsewhere, or the overwhelming majority who are law-abiding 'model' citizens.

Opponents of the government position focus on the social damage done to the asylum-seekers under current detention regimes, concentrating on the deserving refugees and their contribution to Australian society. Often they draw on the context of the government's acceptance of Indo-Chinese refugees in the late 1970s, and their descendants' financial and community success, to present refugees in general as worthy contributors to Australian society. These advocates propose that the Government release the asylum seekers from indefinite detention and permit them to apply to settle in Australia. 


\section{Conclusion: resisting ethnocratic power through building counter-narratives of resilience}

Australia has experienced the full range of being both colony and imperial centre, Indigenous homeland and settler society. It is the North in the South, with the implications of that coming to bear in the current refugee crisis. The two narratives of national solidarity, the one singular, White and Anglo-Christian, the other multiple, rainbow and polyfaith, have never before confronted each other so dramatically and with such complex mis-alignments. The ethnocratic reality of hierarchical difference sits uncomfortably with the multicultural ideology of equality and opportunity.

In attacking the Fraser Government's decision to permit the settlement of Lebanese-Muslim refugees in Australia, Peter Dutton, as Immigration Minister, was advocating ethno-religious selectivity if not outright discrimination in Australian migration policy. In later comment, he signalled his Department was reviewing policies, and that 'if we feel there are problems with particular cohorts, particular nationalities, particular people who might not be integrating well and not contributing well, then there are many other worthy recipients'; in this context he revealed the Department was already discriminating in favour of Christians fleeing the conflict in Syria (Davidson 2016). Further, by ethnicising terror crime as inter-generational, the Minister was also attacking multiculturalism. Here, Dutton directly linked terrorism to ethno-religious identity, not just that of the accused terrorists but also that of their grandparents. As such he was seeking to overturn the liberal civic precept of multiculturalism, that all citizens should be judged by their actions not by their ethnicity. This exploitation of ethnic difference for political gain is part of complex dynamic of inclusion, exclusion, integration and isolation in Australia.

The vast majority of those who are the descendants of the refugees of the 1970s today demand to be included as part of the Australian national narrative, yet face a media pack and political elite who want the right to insult and offend them whenever they wish. While the overarching term used by policy developers remains the idea of social cohesion (Markus 2015), that is, being aware of how much opportunity for the individual depends on the survival of the whole, the edges between different perceptions are becoming sharper as fear and distrust rise, and trust and acceptance decline. 
As clearly borne-out in its recent history, Australian political culture rewards ethnocratic assertion. Politicians can sometimes mobilise ‘their' ethnic bloc, and seek to use the state to consolidate an ethnocratic power base. Politicians, and sensationalising media outlets, do so today as an ostensibly 'reasonable' reaction to reciprocal ethno-political mobilisation via global insurgencies and would-be terror organisations. Ethnic mobilisation, both from 'above' and 'below', becomes a lightning rod for discontent, repressing other social conflicts, whether over gender or class for instance. In this way, ethnocratic politics can indeed become a 'carnival of reaction' as flagged in the Introduction to this Special Issue, a carnival where the state is the prime orchestrator. Arguably, this ostensibly reciprocal logic of ethnic exclusion, presented as a reasonable and fair state strategy, offers a key normative foundation for what in Australia and elsewhere has become an unapologetic and explicit assertion of the right to discriminate against ethnic 'others'. In this context we can conceptualise a form of ‘ethnocratic securitisation', dependent on its threatening 'other' for ideological legitimacy.

Yet, still, there is no total collapse into ethnocratic politics, rather a heightened public engagement and polarisation. In the Australian context, as discussed in this article, as ethnocratic underpinnings are revealed, the anti-ethnocratic and humanitarian response can sharpen. As reflected in the TV documentaries discussed in this article, there can be a reassertion of the energy and creativity that comes from the interaction of difference, the excitement of innovation and the productivity of engagement. Australia in this respect balances on the cusp between democratic pluralism and authoritarian closure. For social scientists the extent to which outcomes can be affected by human choices and intentions remains difficult to determine. Is it more likely that fear and repulsion of the 'other' will surface above acceptance and inclusion? Will the 'other' themselves become be no less fearful and inward looking? While it is possible to resolve these issues so that the society finds greater cohesion, moving in this way requires a scope and intent of purpose by both government and civil society. Yet both the state and the civil world are constantly threatened by forces that would have isolation and exclusion as the preferred outcomes. In the turmoil of the moment it is sometimes difficult to recognise what indeed is taking place at this strategic level.

However the central question, of how open and in which ways Australia will chart a path of democratic pluralism in relation to population-building and creative social and cultural capital, still remains an unresolved and even unspoken challenge. While policy makers focus 
on the short term, massive global population displacements are persistent and likely to be further exacerbated by the impact of climate change both in the global South, among Australia’s Pacific neighbours, and more widely. While the government worries at the business opportunities it might inadvertently offer to regional people smugglers, nativist politics blossoms on the back of prejudice, religious intolerance, and populist demagoguery. If the goal is a humane, manageable, economically productive population policy in which global responsibilities and humane aspirations are firmly embedded, the policy debate has a long way to go.

The ethnocratic practices and structures of Australian society have been well documented, if not often called-out in quite the manner pursued in this article. Indeed the emphasis of ethnocratic theory on violent confrontation and the maintenance of order through the imposition of a biased social order by the state, would sit uncomfortably with most expositions of Australian multiculturalism. Yet recognition of an ethnocratic flavour to Australian discussions of cultural diversity, difference, rights and practices, might allow a cleaner and less emotionally-invested conversation about moving towards greater equality. Where the ethnic power of the elites remains manifest in asylum policy it needs to be challenged. A widening of the opportunities is needed, beyond ethnic hierarchy, to broaden participation in the institutions of power. This would serve the democracy of the nation well, and arrive at more humane and unbiased outcomes in public policy.

\section{References}

Anderson, J. 2016, 'Ethnocracy: Exploring and extending the concept', Cosmopolitan Civil Societies: An Interdisciplinary Journal, vol. 8, no. 3.

Anderson, S. 2016, 'Peter Dutton suggests Fraser government made mistake by resettling Lebanese refugees', ABC News, weblog, 22 November 2016, ABC, http://www.abc.net.au/news/2016-11-21/peter-dutton-fraser-made-mistake-resettlinglebanese-refugees/8043624 .

Andrews, K. 2007, 'Australia's Refugee and Humanitarian Programme, and skilled migration ', http://pandora.nla.gov.au/pan/67564/200711100000/www.minister.immi.gov.au/media/media-releases/2007/ka_doorstop_0715.html, Doorstop interview 3 October.

Betts, K. 2008, 'The 2007 Australian Election: blue-collar voters, migrants and the environment', People and Place, vol. 16, no. 2, pp. 71-85.

Bolt, A. 2016, 'Politicians must acknowledge that culture counts - it must be a factor when deciding who we let into Australia', Bolt Report/ Sky News, facebook, https://www.facebook.com/theboltreport/videos/343440509347418/ 
Borowski, A. 2000, 'Creating a virtuous society: Immigration and Australia's policies of multiculturalism', Journal of Social Policy, vol. 29, no. 3, pp. 459-75. doi: https://doi.org/10.1017/S0047279400006036

Brown, G. 2016, 'No Advantage?: Lessons from Australia’s Experiments in Asylum Policy', Georgetown Journal of International Affairs, vol. 17, no. 1, pp. 20-7. doi: https://doi.org/10.1353/gia.2016.0005

Brown, T. \& Missbach, A. 2016, 'The boats may have 'stopped', but more refugees are stuck in limbo in Indonesia', The Conversation, 22 March 2016 https://theconversation.com/the-boats-may-have-stopped-but-more-refugees-arestuck-in-limbo-in-indonesia-56152 .

Clack, P. 2000, 'Illegal immigrants place huge strain on resources', The Sunday Canberra Times, 15 October, p. 24.

Colebatch, H. 2010, 'The Left rewrites its history on refugees', Quadrant, vol. LIV, no.10, https://quadrant.org.au/magazine/2010/10/the-left-rewrites-its-history-on-refugees/

Davidson, H. 2016, 'Australia is paying for Malcolm Fraser's immigration mistakes, says Peter Dutton', The Guardian Australia, 18 November. https://www.theguardian.com/australia-news/2016/nov/18/australia-paying-forimmigration-mistakes-made-by-malcolm-fraser-says-peter-dutton

Editorial. 2001, 'Illegal immigration ', The Spanish Herald, 10 April, p. 6.

Eureka Research 1998, The anti-racism campaign: Quantitative market research to guide campaign development, Multicultural Affairs Branch, Anti-Racism Campaign Unit, Department of Immigration and Multicultural Affairs Canberra. released under FOI FA11/07/00962 and available at: https://andrewjakubowicz.com/publications/antiracism1998

Gordon, J. \& Topsfield, J. 2006, 'Our values or go home: Costello', The Age (24 February 2006), 12 September 2012. http://www.theage.com.au/news/national/our-values-orgo-home-costello/2006/02/23/1140670207642.html

Harrison, D. 2007, 'African refugees face integration issues: Andrews', The Age, October 3.

Hewson, J. 2016, 'Dutton's attack on Fraser shows how low our politicians are willing to go on refugees', The Conversation, 23 November 2016, https://theconversation.com/duttons-attack-on-fraser-shows-how-low-our-politiciansare-willing-to-go-on-refugees-68648 .

Higgins, C. 2016, 'New evidence on refugee status determination in Australia, 1978-1983', Refugee Survey Quarterly, http://rsq.oxfordjournals.org/content/early/2016/06/22/rsq.hdw008 doi: 10.1093/rsq/hdw008

Humphrey, M. 2007, 'Culturalizing the abject: Islam, law and moral panic in the West', Australian Journal of Social Issues vol. 42, no. 1, pp. 9-25.

Jakubowicz, A. (ed.) 1994, Racism, Ethnicity and the Media, Allen and Unwin, Sydney. Jakubowicz, A. 1997, 'In pursuit of the anabranches: Immigration, multiculturalism and a culturally diverse Australia', in G. Gray \& C. Winter (eds), The Resurgence of Racism; Howard, Hanson and the Race Debate, Monash Publications in History, vol. 24, Department of History, Monash University, Clayton, Vic.

Jakubowicz, A. 2007, 'Political Islam and the future of Australian multiculturalism', National Identities, vol. 9, no. 3, pp. 265-80. http://dx.doi.org/10.1080/14608940701406252

Jakubowicz, A. 2009, 'Masculinity, culture and urban power: the Cronulla conflicts and their amplification in popular media', in Noble, G. (ed.), Lines in the Sand, The Cronulla Riots, Multiculturalism and National Belonging, Institute of Criminology, Sydney, pp. 169-184. 
Jakubowicz, A. 2010, Australia’s migration policies: African dimensions, Australian Human Rights Commission. https://www.humanrights.gov.au/publications/africanaustralians-project-australia-s-migration-policies-african-dimensionsaustralia

Jakubowicz, A. 2015, "In the beginning all is chaos...': Roaming the dystopic realm in Australian multiculturalism', in Castles, S. Ozkul,D. \& Cubas, M.A. (eds), Social Transformation and Migration, Palgrave Macmillan, Houndsmills, pp. 221-36. doi: https://doi.org/10.1057/9781137474957_14 and https://doi.org/10.1057/9781137474957.0025

Jakubowicz, A. n.d., 'The Blainey Debate on Immigration', Making Multicultural Australia, http://www.multiculturalaustralia.edu.au/history/timeline/period/Multiculturalism-inPractice/screen/12.The-Blainey-debate-on-immigration

Jupp, J. 2002, 'Ethnicity and immigration', in Warhurst, J. \& Simms, M. (eds), 2001: The Centenary Election, University of Queensland Press, Brisbane, St Lucia, pp. 261-270.

Jupp, J. 2007, From white Australia to Woomera : the story of Australian immigration, 2nd edn, Cambridge University Press, Melbourne, Vic..

Jupp, J., Nieuwenhuysen, J.P. \& Dawson, E. (eds) 2007, Social cohesion in Australia, Cambridge University Press, Melbourne, Vic. doi: https://doi.org/10.1017/CBO9780511720222

Lewins, F. 1984, 'The significance of factors influencing early Vietnamese settlement in Australia', Journal of Intercultural Studies, vol. 5, no. 2, pp. 29-48. doi: https://doi.org/10.1080/07256868.1984.9963257

Lewins, F. 1987, ' "The Blainey Debate” in Hindsight', Australian \& New Zealand Journal of Sociology, vol. 23, no. 2, pp. 261-73. doi: https://doi.org/10.1177/144078338702300207

Mackellar, M. 1977, Statement by Minister for Immigration and Ethnic Affairs, House of Representatives, Canberra, Debate, 24 May 1977, p. 1713-16. doi: https://doi.org/10.1093/jrs/fev010

Markus, A. 2015, Mapping Social Cohesion: The Scanlon Foundation surveys 2015, Scanlon Foundation, Australian Multicultural Foundation, Monash University, http://scanlonfoundation.org.au/wp-content/uploads/2015/10/2015-Mapping-SocialCohesion-Report.pdf

Marr, D. \& Wilkinson, M. 2003, Dark Victory, Allen and Unwin, Sydney.

McGuirk, R. 2016, 'Australian prime minister did not tell Trump of refugee deal', The Washington Post, 13 November 2016.

Monsour, A. 2007, 'Becoming White: How early Syrian/Lebanese in Australia recognised the value of whiteness', in Boucher, L.,Carey, J. and Ellinghaus, K. (eds), Historicising Whiteness: Transnational Perspectives on the Construction of an Identity, Historicising Whiteness Conference, Melbourne, Vic, Australia, pp. 124-132. 22-24 November 2006.

Morton, R. 2016, 'Data shows migrant welfare clusters', The Australian, 18 November 2016, http://www.theaustralian.com.au/national-affairs/data-shows-migrant-welfareclusters/news-story/81257effae73e55cc5e5c9f231711a1e

Neumann, K. 2015, Across the Seas: Australia's Response to Refugees - a History, Black Inc. , Melbourne.

Ngo, T. 2011, Once Upon a Time in Cabramatta, SBS, 8th January 2012, viewed 15 October 2016, http://www.sbs.com.au/programs/onceuponatimein/seasons/cabramatta

Noble, G., Poynting, S. \& Collins, J. 2000, Kebabs, Kids, Cops and Crime: Youth, Ethnicity and Crime, Pluto Press, Sydney.

Parliament of Australia. Joint Standing Committee on Migration 2016, Inquiry into Migrant Settlement Outcomes, Parliament of Australia, Canberra, 
http://www.aph.gov.au/Parliamentary_Business/Committees/Joint/Migration/settleme ntoutcomes

Pullan, W. \& Baillie, B. (eds) 2013, Locating Urban Conflicts: Ethnicity, Nationalism and the Everyday, Palgrave Macmillan, Houndmills.

Rivett, K. (ed.) 1962, Immigration: control or colour bar? : the background to "White Australia" and a proposal for change, with a historical chapter by David Johanson, Revised and enlarged edn, Melbourne University Press for Immigration Reform Group, Melbourne.

Sampson, R. 2015, 'Caring, contributing, capacity building: Navigating contradictory narratives of refugee settlement in Australia', Journal of Refugee Studies, vol. 29, no.1, pp. 98-116.

Senate, Standing Committee on Foreign Affairs and Defence 1976, Australia and the Refugee Problem: the plight and circumstances of Vietnamese and other refugees, AGPS, Canberra.

Sheehan, P. 2006, 'How the politics of sheer populism led to racial riots', Sydney Morning Herald, 16 January 2006.

Tabar, P., Noble, G. \& Poynting, S. 2003, 'The rise and falter of the field of ethnic politics in Australia: The case of Lebanese community leadership', Journal of Intercultural Studies, vol. 24, no. 3, pp. 267-87. doi: https://doi.org/10.1080/0725686032000172605

Tavan, G. 2004, 'The dismantling of the White Australia policy: Elite conspiracy or will of the Australian people?', Australian Journal of Political Science, vol. 39, no. 1, pp. 109-25. doi: https://doi.org/10.1080/1036114042000205678

Thomas, J. 2015, 'The Vietnamese refugees who changed white Australia', SBS, http://www.sbs.com.au/news/article/2015/04/14/vietnamese-refugees-who-changedwhite-australia .

Tsiolkas, C. 2013, 'Why Australia Hates Asylum Seekers', The Monthly, September 2013, https://www.themonthly.com.au/issue/2013/september/1377957600/christostsiolkas/why-australia-hates-asylum-seekers.

van Dijk, T. 1991, Racism and the Press, Routledge, London.

Vanstone, A.M. 2004, Australia says yes to refugees: a resource for primary schools [information kit], Department of Immigration and Multicultural and Indigenous Affairs, Canberra.

Yiftachel, O. 2006, Ethnocracy: Land and identity politics in Israel/Palestine, University of Pennsylvannia Press, Philadelphia.

\section{Acknowledgements}

The author thanks the editor James Goodman and two anonymous reviewers for their speedy and spectacular contribution to the logic, evidence base and readability of this article.

\section{Statement of Conflict of Interest}

The author is unaware of any conflicts of interest.

\section{Funding}

This paper was produced without funding. 